\title{
What do we know about internationalization strategies implementation and what are we missing?
}

Kelly Cristiny Chinelato Sacramento ${ }^{1}$

Faculdade de Economia, Administração e Contabilidade da Universidade de São Paulo, FEA/USP, São Paulo, SP, Brazil

ARTICLE DETAILS

Article history:

Received: 20 December 2017

Reviewed: 09 February 2018

Accepted: 25 April 2018

Available online: 01 May 2018

Double Blind Review System

\section{Scientific Editor}

Leonardo Aureliano da Silva

\section{Keywords:}

Internationalization strategy Internationalization process Strategic implementation Key factors

Internal factors

\begin{abstract}
Internationalization is a particular kind of strategy that can be described as a complex and multidimensional decision process. However, good strategies do not guarantee business success unless they are successfully implemented. This study aims to investigate what are the key internal factors that impact the implementation of the internationalization strategy of the firm. We conducted a descriptive review of the literature, on articles in the ISI Web of Science database, followed by the use of categorical analysis technique. Results show that antecedents represent most of internationalization studies and little attention has been given to the key internal factors. In addition, most of the discussion focus on Internal Context issues (organizational structures, relationship between business units and people/leadership capabilities), but key factors concerning the Strategic Implementation Process (communication, commitment and control systems) have been neglected by researchers and compromise the holistic understanding of the internationalization process. In this study, we propose an analytical framework bridging the strategy and internationalization perspectives on the issue of implementation and indicate gaps in the internationalization body of research concerning the key internal facts. In doing so, we expect to contribute by providing a systematic understanding of the key factors influencing the implementation of internationalization strategies.
\end{abstract}

(C) 2018 Internext | ESPM. All rights reserved!

\section{INTRODUCTION}

Internationalization is a particular kind of strategy that can be described as a complex and multidimensional decision process (Kraus et al., 2016), and that has gained prominence in the last few decades among business researchers and practitioners with the expressive growth in international business activity, especially by internationalizing firms from the emerging economies (Yaprak et al., 2011). However, good strategies do not guarantee business success unless they are successfully implemented (Ho et al., 2014). Most initiatives fail to reach their full potential (Cândido \& Santos, 2015), despite an increasing number of companies dedicating time and money to mapping the market, gathering knowledge and surveying options to develop better strategies
(Leonardi, 2015), hence the importance of implementation to achieve business goals.

Multiple factors impact the success or failure of implementing a pre-determined strategy (Li et al., 2008; Okumus, 2001) and many of these attributes are internal to the organization and not external to it (Nutt, 1987). Nevertheless, the firm internationalization literature has focused primarily on the antecedents of the strategic decision to enter foreign markets, rather than its execution. In addition, factors influencing the outcomes of internationalization have not received systematic analysis (Carr et al., 2010).

In this study, we bridge the theory of business internationalization and strategic implementation in order to answer what are the key internal factors that impact the implementation of the 
internationalization strategy of the firm. In doing so, we expect to contribute by providing a systematic framework for factors analysis and indicating eventual gaps in the internationalization body of research.

In order to answer that main research question, secondary objectives were established: (i) to identify the implementation stages and the parallels between the two literatures; and (ii) describe and analyze how implementation is being discussed and the research gaps in the internationalization literature. Aiming to provide a more in-depth analysis of the current state of the literature on the key internal factors, we conducted a descriptive and extensive review of the literature, focused on articles in the ISI Web of Science database, chosen as a relevant repository of international scientific production. With no timelimit, the search returned 460 articles and these preliminary results were then analyzed and categorized, resulting in 22 articles involving some type of key internal implementation factor and analysis.

We start this study by reviewing the relevant literature about strategic implementation and the internationalization perspective on implementation, proposing an analytical framework of implementation considering the parallels of the strategy and internationalization perspectives. After presenting the methodological procedures, we conduct descriptive and qualitative analyses over the selected articles. At last, we discuss the results, limitations and future researches opportunities.

We found out that antecedents, motivations or the strategy content make up the vast majority of research on internationalization studies, and comparatively very little attention has been given to the key internal factors. Also, there seems to be no big debates over the Internal Context factors (organizational structures, relationship between business units and people/leadership capabilities), but most of the work is empirical and there is no sign of a consolidated theory on this matter. And most important, that are some key issues, mainly concerning the Strategic Implementation Process (communication, commitment and control systems) that might have been seriously neglected by internationalization researchers and therefore represents a gap in the holistic understanding of the internationalization process and a prolific field for future research.

\section{LITERATURE OVERVIEW}

\subsection{Strategic implementation}

Good strategies do not guarantee business success unless they are successfully implemented (Ho et al., 2014). Most initiatives fail to reach their full potential (Cândido \& Santos, 2015), despite an increasing number of companies dedicating time and money to mapping the market, gathering knowledge and surveying options to develop better strategies (Leonardi, 2015), hence the importance of implementation to achieve business goals. From the strategy literature perspective, strategic implementation can be understood as "a dynamic, interactive and complex process composed of a series of decisions and activities by managers and employees - impacted by a number of interrelated internal and external factors - to turn strategic plans into reality in order to achieve strategic objectives "(Li et al., 2008, p.6).

Multiple factors impact the success or failure of implementing a pre-determined strategy, and many of these attributes are internal to the organization and not external to it (Nutt, 1987). The main influential factors found in the strategy literature can be classified from a structural perspective, also known as "hard factors" and a perspective of interpersonal processes, also called soft factors (Skivington \& Daft, 1991; Nobel, 1999) and a combination of both perspectives may occur (Li et al., 2008).

The structural perspective includes issues related to organizational structure (Olson et al., 2005; Drazin \& Howard, 1984) and management and control mechanisms (Kaplan \& Norton, 2001; Hrebiniak, 2006). The perspective of interpersonal processes involves a range of behavioral and cognitive issues (Noble, 1999), covering the quality of communication (Forman \& Argenti, 2005; Rapert et al., 2002; Alexander, 1985), leadership capabilities (Nutt, 1987; Hrebiniak, 2006; Govindarajan, 1988), team commitment (Hrebiniak, 2006; Heracleous, 2000; Noble \& Mokwa, 1999) and the relationship between different units (Walker \& Ruekert, 1987; Gupta, 1987; Chimhanzi, 2004). Li, Guhui and Eppler (2008) identified these as the most recurrent internal key factors in the strategy implementation literature, plus another one called 'strategy formulation' that refers to the consistency of the strategic plan to assure an implementation success. 
The main constraints and facilitators found in the literature are directly associated with the key factors attributed to the implementation process and are supported by empirical evidence researched with market executives (Hrebiniak, 2006; Viseras et al., 2005; Kaplan \& Norton, 2001). For instance, the Communication factor would be compromised if there was a lack of clarity in the definition and dissemination of tasks, critical activities of implementation and those responsible (Rapert et al., 2002; Alexander, 1985), ineffective disclosure of global strategic decision goals for all levels of the company (Peng \& Litteljohn, 2001), or even difficulty of access and communication by employees and lower administrative levels with top management (Forman \& Argenti, 2005). In addition, constraints regarding the 'Commitment' factor, such as the lack of ownership of the critical employees for the implementation (MacMillan \& Guth, 1985), managers' negative perception of the likely results of the strategy (Noble \& Mokwa, 1999); or the misalignment of interests and individual needs in relation to the expected result (Hrebiniak, 2006; Heracleous, 2000), might harm the potential results of the internationalization process.

Another possible classification for the key factors that contribute to the success of a strategic initiative would be according to the steps of the implementation process: strategic content, context (internal and external), strategic process and outcome (Okumus, 2001). The strategic content refers to the development and direction of the strategy itself. The external and internal strategic contexts deal with uncertainties of the environment and organizational structure, culture and leadership, respectively. The operational process includes allocation of resources and tasks, as well as communication and control. And, finally, the results address the delivery of the entire implementation process (Okumus, 2001). The steps are complementary and non-sequential, so each one must be executed correctly in order to obtain the best results with the strategic implementation. Table 1 summarizes the main influential factors, categorizing them according to the stage of implementation in which they are most relevant.

\subsection{Internationalization perspective on implementation}

Internationalization is a particular kind of strategy and can be described as a complex and multidimensional decision process (Kraus et al.,
2016). In this process, isn't enough to design and plan the corporate global strategy also, because implementing it successfully involves some different and relevant challenges (Hrebiniak, 1992). Nevertheless, the firm internationalization literature has focused primarily on the antecedents of the strategic decision to enter foreign markets ( Li \& Deng, 2017; Schu et al., 2016; Laamanen et al., 2012; Keen \& Eteman, 2012), rather than its execution. In addition, factors influencing the outcomes of internationalization have not received systematic analysis (Carr et al., 2010).

It must be added that the few studies that aim to clarify the international strategy implementation focus only on some specific trait or literature parallel as innovation (Barbosa and Romero, 2016), reshoring strategies (Ocicka, 2016) or political parties (Thrassou et al., 2011), for example. One noticeable exception is the Yaprak, Xu and Cavusgil (2011) attempt to call attention to the interplay among strategy, structure and process in affecting international performance, highlighting a lot of incongruence between internationalization strategy and internal structure and process, but yet failing to provide a comprehensive approach to the key implementation factors that drives internationalization strategy success.
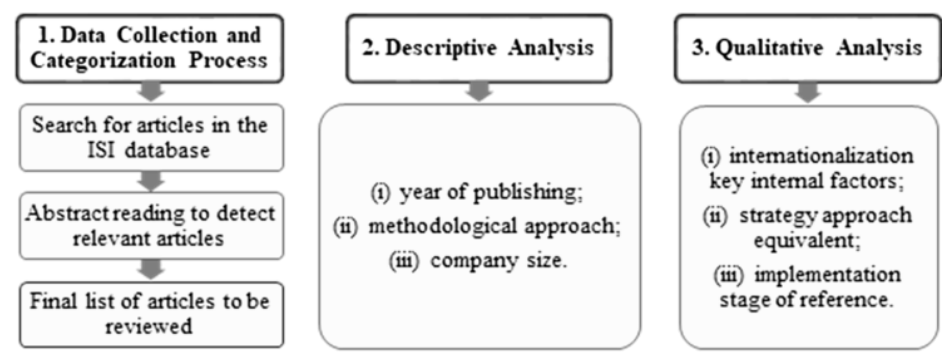

Fig. 1

Data analysis plan

Source: Elaborated by the authors.

Using Okumus (2001) stages-framework and Li, Guhui and Eppler (2008) recurrent key internal factors, it's possible to draw a parallel between the strategy and the internationalization literatures, categorizing the key factors for implementing internationalization strategies, as show on Figure 1. For example, the main decisions of internationalization identified as international orientation, international marketing skills, international innovativeness and international market orientation (Knight \& Kim, 2009) can be related to the 'strategic formulation and decisions' aspect of the implementation and therefor to the 'strategic content stage'. In these stage, both 
Tab. 1

Analytical framework of implementation in the strategy and internationalization perspectives.

\begin{tabular}{|c|c|c|}
\hline $\begin{array}{l}\text { Implementation } \\
\text { Stage }\end{array}$ & $\begin{array}{c}\text { Key factors } \\
\text { Strategy Perspective }\end{array}$ & $\begin{array}{c}\text { Key factors } \\
\text { Internationalization Perspective }\end{array}$ \\
\hline $\begin{array}{l}\text { Strategic } \\
\text { Content }\end{array}$ & $\begin{array}{l}\text { Strategic formulation and decisions: the direction of the strategy } \\
\text { must be consistent, accurate and adequate to the company's } \\
\text { capabilities; }\end{array}$ & $\begin{array}{l}\text { International orientation; International marketing skills; } \\
\text { International innovativeness; International Market } \\
\text { orientation. } \\
\text { (Knight \& Kim, 2009) }\end{array}$ \\
\hline $\begin{array}{l}\text { External } \\
\text { Context }\end{array}$ & $\begin{array}{l}\text { Environmental uncertainty: in the general and task environment } \\
\text { must be monitored; }\end{array}$ & $\begin{array}{l}\text { Technological shifts (Vissak \& Francioni, 2013); } \\
\text { Institutional frameworks (Vaillant \& Lafuente, 2007); } \\
\text { Government policies and incentives (Carter \& Wilton, } \\
\text { 2006). }\end{array}$ \\
\hline \multirow[t]{3}{*}{ Internal Context } & $\begin{array}{l}\text { Organizational structure: the operational structure must be aligned } \\
\text { with the strategy, and must be adjusted so that the corporate } \\
\text { environment is conducive to implementation; }\end{array}$ & $\begin{array}{l}\text { Degree of internationalization (DOI) (Kraus et al., 2016); } \\
\text { Manufacturing flexibility (Chiesa, 1996); }\end{array}$ \\
\hline & $\begin{array}{l}\text { Relationship between business units: the degree of autonomy of } \\
\text { the units, formal programs of sharing and the synergy obtained } \\
\text { positively impact the implementation, while conflicts and } \\
\text { misalignments can harm it; }\end{array}$ & $\begin{array}{l}\text { Business networks (Hendry, 1996); Knowledge transfer } \\
\text { (Williams \& Nones, 2009); Management and subsidiary } \\
\text { autonomy } \\
\text { (Gilbert \& Heinecke, 2014; Gammelgaard et al., 2012); }\end{array}$ \\
\hline & $\begin{array}{l}\text { People/ leadership: the effectiveness of the strategy depends on } \\
\text { the quality (skills, attitudes, skills and experiences) of the people } \\
\text { involved in the process and should be analyzed at three levels: } \\
\text { senior management, middle management and non-managers; }\end{array}$ & $\begin{array}{l}\text { Family involvement on firm (Kraus et al., 2016); } \\
\text { Managers competence (Efrat \& Shoham, 2012); } \\
\text { Subsidiaries personnel development (Williams \& Nones, } \\
\text { 2009); Expatriates cultural fit } \\
\text { (Nawab et al., 2011) }\end{array}$ \\
\hline \multirow[t]{3}{*}{$\begin{array}{l}\text { Strategic } \\
\text { Process }\end{array}$} & $\begin{array}{l}\text { Communication: Adequate alignment and correct understanding of } \\
\text { the motivations, outcomes and expected results of the strategy } \\
\text { with all stakeholders avoid rework and accelerate implementation; }\end{array}$ & Socialization (Borini et al., 2012). \\
\hline & $\begin{array}{l}\text { Commitment: The involvement and commitment of all employees } \\
\text { must be continually developed and boosted throughout the } \\
\text { implementation; }\end{array}$ & Management commitment (Javalgi \& Todd, 2011); \\
\hline & $\begin{array}{l}\text { Management / control systems: control systems and corporate } \\
\text { policies favor implementation, as they allow to monitor their } \\
\text { development, highlighting divergences with agility; }\end{array}$ & $\begin{array}{l}\text { Subsidiary performance evaluation (Miao et al., 2011); } \\
\text { Team compensation level (Lin \& Cheng, 2013). }\end{array}$ \\
\hline Outcomes & Results: tangible and intangible outcomes of the strategy. & $\begin{array}{l}\text { Export growth (Rock \& Ahamed, 2014); Global } \\
\text { performance impact } \\
\text { (Gammelgaard et al., 2012). }\end{array}$ \\
\hline
\end{tabular}

literatures emphasize the importance of culturalstrategy alignment (Gammeltoft et al.,2012; Alexander, 1985) and exhausting information gathering to avoid difficulties arising from unpredictable external factors (Gilad, 2004; Danik \& Kowalik, 2015; Garret \& Lange, 1995).

On the other hand, the 'external context' stage will deal with government policies and incentives (Carter \& Wilton, 2006; Knill \& Lehmkuhl, 2002; Garret \& Lange, 1995), institutional frameworks (Vaillant \& Lafuente, 2007; Calof \& Beamish, 1995), technological shifts (Vissak \& Francioni, 2013) and all the different external triggers (Numella et al., 2016) that are out of the firm's control and therefore implies environmental uncertainty (Okumus, 2001). And although these external factors are extremely important, especially for short-term results, it's the internal factors that become more crucial to the firm's long-term internationalization success (Jormanainen \& Koveshnikov, 2012).
The 'internal context' stage will raise important issues related to the organizational structure (Kraus et al., 2016; Chiesa, 1996), the relationship between business units (Hendry, 1996; Williams \& Nones, 2009; Gilbert \& Heinecke, 2014; Gammelgaard et al., 2012) and to people/leadership capabilities (Kraus et al., 2016; Efrat \& Shoham, 2012; Williams \& Nones, 2009; Nawab et al., 2011). The 'strategic process' will discuss different internal aspects of the implementation, such as communication (Borini et al., 2012), commitment (Javalgi \& Todd, 2011) and management/control systems (Miao et al., 2011; Lin \& Cheng, 2013). Table 1 synthesizes the analytical framework of implementation in the strategy and internationalization perspectives.

\section{METHODOLOGICAL PROCEDURES}

In as effort to identify the key internal factors that impact the implementation of the internationalization strategy of the firm we conducted a descriptive and extensive review of the 
literature. We first conducted a search for journal articles utilizing the ISI- Web of Knowledge database, chosen as a relevant repository of international scientific production. The search terms included internationalization or internationalization associated with the terms factor, variable or driver with no time-limit, but restricted to the business and management subject area within which the search was conducted. The search returned 460 articles and these preliminary results were then analyzed for an indication of relevance to the field of strategic implementation. Often, the abstracts provided us with ample information about the methods and unit of analysis. Based on a reading of these abstracts, we were able to eliminate the many articles that focused on antecedents of internationalization or used internationalization as a context instead of the analysis subject or yet didn't have companies as the main unit of analysis. We found that antecedents and motivations make up the vast majority of research on internationalization studies.

Once relevant articles and potentially relevant articles were identified, we went on to read the complete articles to make sure that each fit the requirements of the search. At this point we identified and discarded articles discussing strategic content or external context variables. Each article that fulfilled the requirement of focusing on business internationalization studied at the strategic implementation level of analysis and focusing on internal key factors was then indexed. Our final list of reviewed articles included 22 studies. All studies included in our review had to involve some type of key internal implementation factor and analysis. Some studies included content or external context findings but were included if they also showed results at the internal context or strategic process stages.

The 22 studies were analyzed using the categorical analysis technique, one of the dimensions of content analysis proposed by Bardin (1979). A summary was then produced for each article, which listed the categories: year of publishing, company size (SME small and medium enterprises or MNC multinational corporates), methodological approach (theoretical or empirical), the internationalization key internal factors analyzed, their strategy approach equivalent and the implementation stage they refer to. The article summaries provided us with easily identifiable markers for comparisons of the research being conducted in the field. Figure 1 demonstrates the main steps of the research.

\subsection{Results Analysis}

In this section, we analyze the 22 reviewed articles as described in the methodological procedures, in order to identify the key internal factors that impact business internationalization strategies.

\subsection{Descriptive Analysis}

Although we did not impose any time-limit to the research, the results we found when we examined the articles per year of publishing revealed that the concern about internal key factors for strategic implementation is a reasonably new issue in the business internationalization literature. As Figure 2 demonstrates, $91 \%$ of the reviewed articles were published in the last 10 years. Only 2 articles (Hendry, 1996; Chiesa, 1996) were published earlier and can be considered among the pioneers on the matter.

Fig. 2

Researched articles distributed per year of publishing.

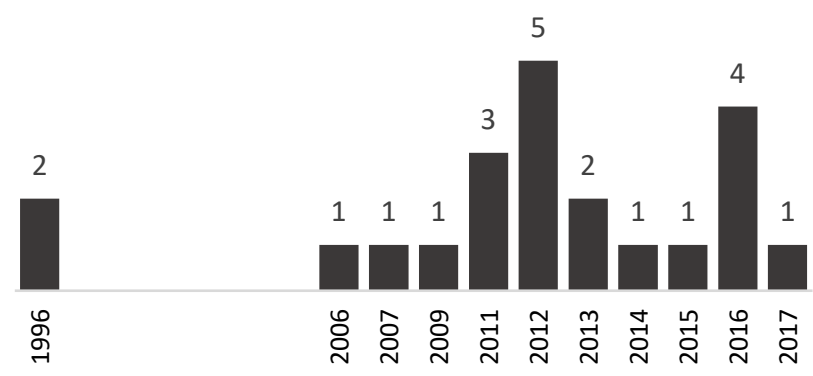

Source: Elaborated by the authors.

Most of the articles reviewed (86\%) presented an empirical methodological approach (Figure 3), based mostly on primary data collection via interviews and surveys. The predominance of empirical studies reinforces the developing aspect of the theory (Cooper et al., 2006), as researchers are still collecting information from the field, in order to expand their comprehension of the implementation issue in the business internationalization context.

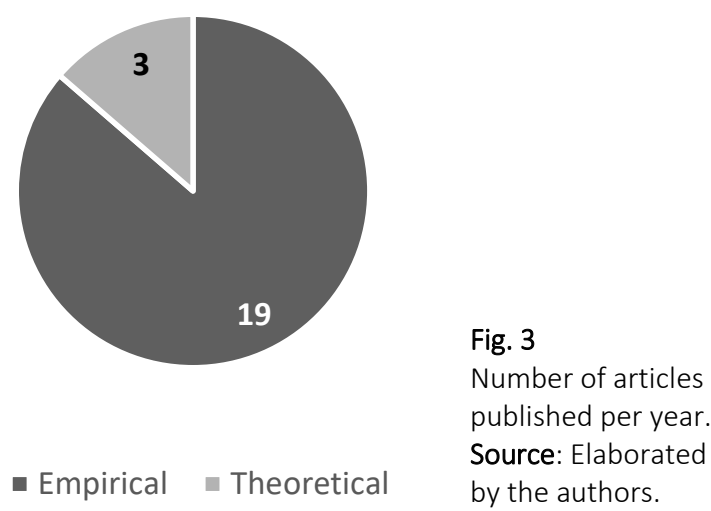


Tab. 2

Relevance of the key internal factors of strategic implementation in the internationalization literature

\begin{tabular}{cllc}
\hline \multirow{2}{*}{ Implementation Stage } & $\begin{array}{l}\text { Strategic } \\
\text { Key Factor }\end{array}$ & Key Factors of Internationalization & $\begin{array}{c}\text { N. } \\
\text { Articles }\end{array}$ \\
& Organizational structure & Manufacturing flexibility & 5 \\
& & Degree of internationalization & 1 \\
\cline { 2 - 4 } Internal Context & People/leadership & Managers competence & 4 \\
& & Subsidiaries personnel development & 2 \\
\cline { 2 - 4 } & \multirow{2}{*}{ Relationship between business units } & Expatriates cultural fit & 1 \\
& & Family involvement on firm & 1 \\
\cline { 2 - 4 } Strategic Process & Comanagement and subsidiary autonomy & 6 \\
\cline { 2 - 4 } & \multirow{2}{*}{ Management/control systems } & Knowledge transfer & 3 \\
& & Socialization & 2 \\
\hline
\end{tabular}

Source: Elaborated by the authors.

Note: The sum of the number of articles in Table 1 exceeds the total of 22, because some of the reviewed articles discuss more than one key factor

Figure 4 shows the reviewed articles categorized by the size of company they focus on: MNC or SME. $64 \%$ of the studies focus on MNC and $36 \%$ on SME. This result shows that the issue of the key internal factors for implementation is relevant for either size of company, even considering their particularities.

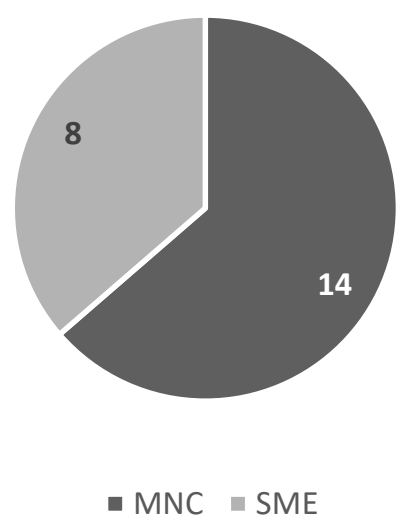

As a whole, the descriptive analysis of the articles reveals the initial stage in which the internal aspects of strategy implementation are found in the business internationalization literature, despite their relevance to different sizes of company. The following qualitative analysis will provide evidence of which aspects are slightly better developed and which have been neglected.

\subsection{Qualitative Analysis}

The qualitative analysis was based on the categorization of the reviewed articles as: (i) the internationalization key internal factors analyzed; (ii) their strategy approach equivalent; and (iii) the implementation stage they refer to. Table 2 consolidates the results of the categorical analysis and reveal the relevance of each key internal factor of strategic implementation in the internationalization literature.

Initially, what draws attention is the fact that Internal Context factors are considerably more researched than the ones concerning the Strategic Process. In reference to the strategic key factor 'Organizational structure' the main issue is the Manufacturing flexibility, discussing matters of centralization or decentralization of the subsidiaries. Chiesa (1996) points out that the degree of dispersion of external sources of knowledge, and the degree of dispersion of the key internal $R \& D$ resources influence the structural outcome. Rodriguez, Wise and Martinez (2013) and Fisch and Zschoche (2011) agree that the flexibility to shift production among subsidiaries, adapting manufacturing processes, and cooperative relationships impacts the firm's innovation and market expansion-adaptation capabilities, increasing profitability of international production networks. In addition, Miozzo and Mo (2012) and Sanna-Randaccio and Veugelers (2007) researches bring evidences that decentralization on the headquarters-subsidiary relationships can provide flexibility and help to take advantages of favorable external factors.

The 'People/leadership capabilities' strategic key factor is one of the most researched internal aspects of the implementation. The Managers competence stands out as being the most preeminent topic in the internationalization literature reviewed and the 
evidences point to the same conclusion, that being that managerial capabilities have a positive influence on the expected outcome. Nummela, Saarenketo and Loane (2016) highlight the importance of managerial experience in filtering the external drivers of failure. In a complementary way, Chebbi, Yahiaoui, Vrontis and Thrassou (2017) reinforce different attributes of leadership (nurturant, personal touch, expertise, simple living and high thinking, loyalty, self-sacrifice, and the giving model of motivation) impact in successful internationalization. Beleska-Spasova, Glaister and Stride (2012) and Efrat and Shoham (2012) add more evidence to the matter, pinning out that managerial capabilities can overshadow physical resources and external factors in affecting positively the international success of a firm.

In regard to the strategic key factor 'Relationship between business units', the reviewed articles focus on Business networks and Autonomy issues. Hendry (1996) and Gammelgaard, McDonald, Stephan, Tuselmann and Dorrenbacher (2012) proposes that business networks is one of the determinants for the creation of an effective international organization. Mort and Weerawardena (2006) explain that link with evidences that fundamental and secondary networking capabilities enable identification and exploitation of market opportunities and facilitates the development of knowledge-intensive products. Stoian, Rialp, Rialp and Jarvis (2016) deepen pointing out that networks play a crucial role for knowledge creation and exchange, and frequently represent the most reliable resource at firms' disposal, and Hashim (2015) complements by stating its role as a way to surpass external difficulties. About the Management/subsidiary autonomy factor, Gilbert and Heinecke (2014) and Gammelgaard, McDonald, Stephan, Tuselmann and Dorrenbacher (2012) agrees that increases in autonomy to an appropriate degree are highly contingent upon contextual influences, and Miozzo and Mo (2012) assigns the contingenct role to the flexibility that it brings to the firm.

In contrast, the Strategic Process factors are noticeably less discussed in the reviewed internationalization literature. Only three researches address the 'Management/ control system' strategic factor. Discussing subsidiary performance evaluation, Miao, Choe and Song (2011) states that subsidiary-toparent knowledge flow is facilitated by establishing efficient formal mechanisms such as an expatriation policy and a subsidiary performance evaluation system. However, Miozzo e Mo (2012) discuss that international tools for integration and co-ordination, including corporate processes and global supply chain management, reinforce centralization, which may lead to less flexibility to take advantages of external factors. On a different topic, Lin and Cheng (2013) show that CEO total compensation level and Management Team Total (TMT) compensation were positively related to firms' international expansion level.

Even more critical, the 'Communication' factor was discussed in only one reviewed article. Borini, Oliveira, Silveira and Concer (2012) showed that organizational communication is vital in reducing uncertainty and disseminating knowledge, therefore the reverse transfer of innovation depends on strong integration (communication) between the parent and its subsidiaries, among other factors. The research builds on the concept of Socialization, defined as "information-processing routines that facilitate the transfer of knowledge from the subsidiary to its parent company, related to the ability to facilitate relationships of trust, create a shared vision, and minimize differences regarding preferences and interests among members in the network, using mechanisms for information exchange that meet the costs and benefits requirements" (Borini et al., 2012).

Finally, it draws attention to the fact that there are no articles addressing the 'Commitment' strategic key factor, related to the continuous involvement and commitment of all employees throughout the implementation.

\section{DISCUSSION, IMPLICATIONS, RESEARCH DIRECTIONS AND LIMITATIONS}

The overall research problem which guided this study was: "what are the key internal factors that impact the implementation of the internationalization strategy of the firm?". To answer that we propose the following specific objectives: to identify the implementation stages and the parallels between the two literatures; and to describe and analyze how implementation is being discussed and the research gaps in the internationalization literature. Therefore, we conducted a descriptive review of the literature, focused on articles in the ISI Web of Science database, chosen as a relevant repository of international scientific production. With no timelimit, the search returned 460 articles and these preliminary results were then analyzed and categorized, resulting in 22 articles involving some 
type of key internal implementation factor and analysis.

The findings highlight that antecedents, motivations or the strategy content make up the vast majority of research on internationalization studies, and comparatively very little attention has been given to the key internal factors, corroborating the research of Carr, Haggard, Hmieleski and Zahra (2010). The descriptive analysis of the reviewed articles confirms the initial stage in which the internal aspects of strategy implementation are found in the business internationalization literature, despite their relevance to different sizes of company. The majority of the articles were published in the last 10 years and are based on empirical evidence, what reinforces the developing aspect of the theory (Cooper et al., 2006), as researchers are still collecting information from the field, in order to expand their comprehension of the implementation issue in the business internationalization context.

The findings also suggest that Internal Context factors (organizational structures, relationship between business units and people/leadership capabilities) are considerably more researched than the ones concerning the Strategic Process (communication, commitment and control systems. In addition, there seems to be no big debates over the Internal Context factors, with most of the results pointing in the same direction about the issue discussed. 'Business networks', 'Management competence' and 'Manufacturing flexibility' were the most discussed key internal factors among the reviewed articles.

In contrast, the Strategic Process factors are noticeably less discussed in the reviewed internationalization literature. The evidences show that 'Communication' and 'Commitment' seem to be the most critical under researched internal factors, overlooked even in studies that attempted to articulate different implementation factors (Yaprak et al., 2011). The results presented by Borini, Oliveira, Silveira and Concer (2012) echo the strategic perspective on the importance of quality communication for successful implementation (Peng \& Litteljohn, 2001), by showing that organizational communication is vital in reducing uncertainty and disseminating knowledge, therefore the reverse transfer of innovation depends on creating a strong shared vision through communication between the parent and its subsidiaries, evidencing the validity of the parallel between both literatures. However, the strategy literature points out other constraints to effective communication that have yet to be addressed by the internalization literature, such as the clear definition and dissemination of tasks and responsabilities (Rapert et al., 2002; Alexander, 1985) and the difficulty of access and communication by employees or subsidiaries with top management or head-quarters (Forman \& Argenti, 2005).

Finally, as that there are no articles addressing the 'Commitment' strategic key factor, related issues such as the lack of ownership of the critical employees for the implementation (MacMillan \& Guth, 1985), managers' negative perception of the likely results of the strategy (Noble \& Mokwa, 1999) or the misalignment of interests and individual needs in relation to the expected result (Hrebiniak, 2006; Heracleous, 2000) might still be an important missing attribute to the holistic understanding of the successful internationalization process.

It is worth mentioning some limitations of this research that concern the delimitation of the database used, being restricted to ISI - Web of Knowledge, and the researched terms used to compose the reviewed articles sample. Although we intended to pursue an extensive research, we do not intend nor imply that it is exhaustive.

We aimed to provide a more in-depth analysis of the current state of the literature on the key internal factors by bridging the theory of business internationalization and strategic implementation. In doing so, we expect to contribute by providing a systematic framework for factors analysis and indicating the main gaps in the internationalization literature. Future researches concerning the implementation of internationalization strategies might be facilitated by the analytical framework provided (Table 1). In addition, some key issues, mainly concerning the Strategic Implementation Process (communication, commitment and control systems) seem to have been seriously neglected by internationalization researchers and therefore represents a gap in the holistic understanding of the internationalization process and a prolific field for future research. 


\section{REFERENCES}

- $\quad$ Alexander, L.D. (1985). Successfully Implementing Strategic Decisions. Long Range Planning, 18, 91-97.

- Barbosa, F., \& Romero, F. (2016, September). The Links Between Innovation, Strategy and Internationalization Processes: A Comprehensive Literature Review. In European Conference on Innovation and Entrepreneurship (p. 904). Academic Conferences International Limited.

- Bardin, L. (1979). Análise de conteúdo. Lisboa: Edições 70

- Beleska-Spasova, E., Glaister, K. W., \& Stride, C. (2012). Resource determinants of strategy and performance: The case of British exporters. Journal of World Business, 47(4), 635-647.

- Borini, F. M., de Miranda Oliveira, M., Silveira, F. F., \& de Oliveira Concer, R. (2012). The reverse transfer of innovation of foreign subsidiaries of Brazilian multinationals. European Management Journal, 30(3), 219-231.

- Calof, J. L., \& Beamish, P. W. (1995). Adapting to foreign markets: Explaining internationalization. International business review, 4(2), 115-131.

- Cândido, C., \& Santos, S.P.D. (2015). Strategy implementation: What is the failure rate?. Journal of Management \& Organization, 21(02), 237-262.

- Carr, J. C., Haggard, K. S., Hmieleski, K. M., \& Zahra, S. A. (2010). A study of the moderating effects of firm age at internationalization on firm survival and short-term growth. Strategic Entrepreneurship Journal, 4(2), 183192.

- Carter, S., \& Wilton, W. (2006). Don't blame the entrepreneur, blame government: The centrality of the government in enterprise development; Lessons from enterprise failure in Zimbabwe. Journal of Enterprising Culture, 14(01), 65-84.

- Chebbi, H., Yahiaoui, D., Vrontis, D., \& Thrassou, A. (2017). The Impact of Ambidextrous Leadership on the Internationalization of Emerging-Market Firms: The Case of India. Thunderbird International Business Review, 59(3), 421-436.

- Chiesa, V. (1996). Managing the internationalization of R\&D activities. IEEE Transactions on Engineering Management, 43(1), 7-23.

- Chimhanzi, J. (2004). The impact of marketing/HR interactions on marketing strategy implementation. European Journal of Marketing, 38, 73-98.

- Cooper, D. R., Schindler, P. S., \& Sun, J. (2006). Business research methods (Vol. 9). New York: McGraw-Hill Irwin.

- Danik, L., \& Kowalik, I. (2015). Success factors and development barriers perceived by the Polish born global companies. Empirical study results. Journal of East European Management Studies, 360-390. Drazin, R. \& Howard, P. (1984). Strategy implementation: A technique for organizational design, Columbia Journal of World Business, 19 (summer), 40-46.

- Efrat, K., \& Shoham, A. (2012). Born global firms: The differences between their short-and long-term performance drivers. Journal of World Business, 47(4), 675-685.

- $\quad$ Fisch, J. H., \& Zschoche, M. (2011). Do firms benefit from multinationality through production shifting? Journal of International Management, 17(2), 143-149.

- Forman, J., \& Argenti, P.A. (2005). How corporate communication influences strategy implementation, reputation and the corporate brand: An exploratory qualitative study. Corporate Reputation Review, 8, 245264.

- Gammelgaard, J., McDonald, F., Stephan, A., Tüselmann, H., \& Dörrenbächer, C. (2012). The impact of increases in subsidiary autonomy and network relationships on performance. International Business Review, 21(6), 1158-1172.

- Garrett, G., \& Lange, P. (1995). Internationalization, institutions, and political change. International Organization, 49(4), 627-655.

- Gilad, B. (2004). Early warning: Using competitive intelligence to anticipate market shifts, control risk, and create powerful strategies. New York, NY: AMACOM.

- Gilbert, D. U., \& Heinecke, P. (2014). Success factors of regional strategies for multinational corporations: Exploring the appropriate degree of regional management autonomy and regional product/service adaptation. Management International Review, 54(5), 615-651.

- Govindarajan, V. (1988). A contingency approach to strategy implementation at the business-unit level integrating administrative mechanisms with strategy. Academy of Management Journal, 31, 828-853.

- Gupta, A.K. (1987). SBU strategies, corporate-SBU relations, and SBU effectiveness in strategy implementation. Academy of Management Journal, 30, 477-500.

- Hashim, F. (2015). SMEs' impediments and developments in the internationalization process: Malaysian experiences. World Journal of Entrepreneurship, Management and Sustainable Development, 11(2), 100-119.

- Hendry, C. (1996). Continuities in human resource processes in internationalization and domestic business management. Journal of Management Studies, 33(4), 475-494.

- Ho, J.L.Y., Wu, A., \& Wu, S.Y.C. (2014). Performance measures, consensus on strategy implementation, and performance: evidence from the operational-level of organizations. Accounting Organizations and Society, 39, 38-58.

- Heracleous, L. (2000). The role of strategy implementation in organization development. Organization Development Journal, 18, 75-86. 
- Hrebiniak, L. (1992). Implementing global strategies. European Management Journal, 10(4), 392-403.

- Hrebiniak, L.G. (2006). Fazendo a estratégia funcionar. Editora Bookman.

- Javalgi, R. R. G., \& Todd, P. R. (2011). Entrepreneurial orientation, management commitment, and human capital: The internationalization of SMEs in India. Journal of Business Research, 64(9), 1004-1010.

- Jormanainen, I., \& Koveshnikov, A. (2012). International activities of emerging market firms. Management International Review, 52(5), 691-725.

- Kaplan, R. S., \& Norton, D. P. (2001). The strategyfocused organization: How balanced scorecard companies thrive in the new business environment. Harvard Business Press.

- Keen, C., \& Etemad, H. (2012). Rapid growth and rapid internationalization: the case of smaller enterprises from Canada. Management Decision, 50(4), 569-590.

- Knight, G., \& Kim, D. (2009). International business competence and the contemporary firm. Journal of International Business Studies, 40(2), 255-273.

- Knill, C., \& Lehmkuhl, D. (2002). Private actors and the state: Internationalization and changing patterns of governance. Governance, 15(1), 41-63.

- $\quad$ Kraus, S., Mitter, C., Eggers, F., \& Stieg, P. (2017). Drivers of internationalization success: a conjoint choice experiment on German SME managers. Review of Managerial Science, 11(3), 691-716.

- Laamanen, T., Simula, T., \& Torstila, S. (2012). Crossborder relocations of headquarters in Europe. Journal of International Business Studies, 43(2), 187-210.

- Leonardi, P.M. (2015). Materializing strategy: The blurry line between strategy formulation and strategy implementation. British Journal of Management, 26, 17-21.

- Li, Q., \& Deng, P. (2017). From international new ventures to MNCs: Crossing the chasm effect on internationalization paths. Journal of Business Research, 70, 92-100.

- Li, Y., Guohui, S., \& Eppler, M.J. Making strategy work: A literature review on the factors influencing stragegy implementation. Università della Svizzera Italiana, 2008.

- Lin, W. T., \& Cheng, K. Y. (2013). The effect of upper echelons' compensation on firm internationalization. Asia Pacific Journal of Management, 30(1), 73-90.

- MacMillan, I.C., \& Guth, W.D. (1985) Strategy implementation and middle management coalitions. Advanced Strategic Management, 3, 233-254.

- Miao, Y., Choe, S., \& Song, J. (2011). Transferring subsidiary knowledge in the global learning context. Journal of Knowledge Management, 15(3), 478-496.

- Miozzo, M., \& Yamin, M. (2012). Institutional and sectoral determinants of headquarters-subsidiary relationships: A study of UK service multinationals in China, Korea, Brazil and Argentina. Long Range Planning, 45(1), 16-40.

- $\quad$ Mort, S.G., \& Weerawardena, J. (2006). Networking capability and international entrepreneurship: How networks function in Australian born global firms. International Marketing Review, 23(5), 549-572.

- Nawab, S., Li, X. X., \& Nisar, M. W. (2011). " Person culture fit" as an approach for better adjustments of expatriates to new cultures: A case study of China. African Journal of Business Management, 5(9), 3429.

- Noble, C.H. (1999). Building the strategy implementation network. Business Horizons, 42(6), 19 28.

- Noble, C.H., \& Mokwa, M.P. (1999). Implementing marketing strategies: developing and testing a managerial theory. Journal of Marketing, 63, 57-73.

- Nummela, N., Saarenketo, S., \& Loane, S. (2016). The dynamics of failure in international new ventures: $A$ case study of Finnish and Irish software companies. International Small Business Journal, 34(1), 51-69.

- Nutt, P.C. (1987). Identifying and appraising how managers install strategy. Strategic Management Journal, 8, 1-14.

- Ocicka, B. (2016). Reshoring: implementation issues and research opportunities. Management, 20(2), 103117.

- Okumus, F. (2001). Towards a strategy implementation framework. International Journal of Contemporary Hospitality Management, 13, 327-338.

- Olson, E.M., Slater, S.F. \& Hult, G.T. (2005). The importance of structure and process to strategy implementation. Business Horizons, 48, 47-54.

- Onkelinx, J., Manolova, T. S., \& Edelman, L. F. (2016). The human factor: Investments in employee human capital, productivity, and SME internationalization. Journal of International Management, 22(4), 351-364.

- Peng, W. \& Litteljohn, D. (2001). Organisational communication and strategy implementation - A primary inquiry. International Journal of Contemporary Hospitality, 13, 360-363.

- $\quad$ Rapert, M.I., Velliquette, A., \& Garretson, J.A. (2002). The strategic implementation process evoking strategic consensus through communication. Journal of Business Research, 55, 301-310.

- $\quad$ Rodriguez, M.C., Wise, A.J., \& Martinez, R.C. (2013). Strategic capabilities in exporting: an examination of the performance of Mexican firms. Management Decision, 51(8), 1643-1663.

- $\quad$ Sanna-Randaccio, F., \& Veugelers, R. (2007). Multinational knowledge spillovers with decentralised R\&D: a game-theoretic approach. Journal of International Business Studies, 38(1), 47-63.

- Schu, M., Morschett, D., \& Swoboda, B. (2016). Internationalization Speed of Online Retailers: A 
Resource-Based Perspective on the Influence Factors. Management International Review, 56(5), 733-757.

- Skivington, J.E., \& Daft, R.L. (1991). A study of organizational framework and process modalities for the implementation of business-level strategic decisions. Journal of Management Studies, 28(1), 4568.

- Stoian, M. C., Rialp, A., Rialp, J., \& Jarvis, R. (2016). Internationalisation of central and eastern European small firms: institutions, resources and networks. Journal of Small Business and Enterprise Development, 23(1), 105-121.

- Thrassou, A., Vrontis, D., \& Kotabe, M. (2011). Towards a marketing communications model for small political parties: A primary principles strategic perspective for developed countries. Cross Cultural Management: An International Journal, 18(3), 263-292.

- Vaillant, Y., \& Lafuente, E. (2007). Do different institutional frameworks condition the influence of local fear of failure and entrepreneurial examples over entrepreneurial activity?. Entrepreneurship and Regional Development, 19(4), 313-337.

- Vissak, T., \& Francioni, B. (2013). Serial nonlinear internationalization in practice: A case study. International Business Review, 22(6), 951-962.

- Viseras, E.M. Baines, T., \& Sweeney, M. (2005). Key success factors when implementing strategic manufacturing initiatives. International Journal of Operations \& Production Management, 25, 151-179.

- Walker, Jr.O.C. \& Ruekert, R.W. (1987). Marketing`s role in the implementation of business strategies: a critical review and conceptual framework. Journal of Marketing, 51, 15-33.

- Williams, C., \& Nones, B. (2009). R\&D subsidiary isolation in knowledge-intensive industries: evidence from Austria. R\&d Management, 39(2), 111-123.

- Yaprak, A., Xu, S., \& Cavusgil, E. (2011). Effective global strategy implementation. Management International Review, 51(2), 179.

\section{ABOUT THE AUTHORS}

- Kelly Cristiny Chinelato Sacramento is a Ph.D. Candidate at the School of Economics, Business and Accounting of the University of São Paulo. She holds a Master of Business Administration from the University of São Paulo and a B.A. in Economics from Campinas State University. With over 10 years of professional experience in business strategy, her main area of research is Business Strategy Implementation.Email: kellysacramento@usp.brORCID: 


\title{
O que sabemos sobre a implementação das estratégias de internacionalização e o que nas falta?
}

\author{
Kelly Cristiny Chinelato Sacramento
}

Faculdade de Economia, Administração e Contabilidade da Universidade de São Paulo, FEA/USP, São Paulo, SP, Brasil

\section{DETALHES DO ARTIGO}

\section{Histórico do Artigo:}

Recebido: 20 de Dezembro de 2017

Revisado: 09 de Fevereiro de 2018

Aceito: 25 de Abril de 2018

Disponível online em: 01 de Maio de 2018

Sistema de revisão "Double blind review"

Editor Científico

Leonardo Aureliano da Silva

\section{Palavras-chaves:}

Estratégia de internacionalização

Processo de internacionalização

Implementação estratégica

Fatores-chaves

Fatores internos

\section{RESUMO}

\begin{abstract}
A internacionalização é um tipo particular de estratégia que pode ser descrita como um processo de decisão complexo e multidimensional. No entanto, boas estratégias não garantem o sucesso a menos que sejam bem implementadas. Este estudo investiga quais os principais fatores internos que impactam a implementação da estratégia de internacionalização da empresa, através de uma revisão descritiva da literatura, em artigos no banco de dados da ISI Web of Science, seguida de técnicas de análise por categorias. Os resultados mostram que antecedentes representam a maioria dos estudos de internacionalização e pouca atenção tem sido dada aos principais fatores internos. Além disso, a maior parte da discussão concentra-se no Contexto Interno (estruturas organizacionais, relações entre unidades de negócios e pessoas / capacidades de liderança), mas fatores-chave sobre o Processo de Implementação Estratégica (sistemas de comunicação, compromisso e controle) foram negligenciados por pesquisadores, comprometendo a compreensão holística da internacionalização. Neste estudo, propomos uma estrutura analítica que articule as perspectivas de estratégia e internacionalização sobre a questão da implementação e indique lacunas no corpo de pesquisa de internacionalização sobre os principais fatores internos. Ao fazê-lo, esperamos contribuir fornecendo uma compreensão sistemática dos principais fatores que influenciam a implementação de estratégias de internacionalização.
\end{abstract}

(c) 2018 Internext | ESPM. Todos os direitos reservados!

To cite this article:

Sacramento, K. C. C. (2018) What do we know about internationalization strategies implementation and what are we missing? Internext - Revista Eletrônica de Negócios Internacionais, 13 (2), 59-70. DOI: http://dx.doi.org/ 10.18568/1980-4865.13259-70

For access this article: http://dx.doi.org/10.18568/1980-4865.13259-70 